\title{
Leaf eating insect damage on different poplar clones and sites
}

\author{
Romica TOMESCU ${ }^{\mathrm{a}}$, Ludovic NEF ${ }^{\mathrm{b} *}$ \\ ${ }^{a}$ Institutul de Cercetări si Amenajări Silvice, Soseaua Stefanesti, 128, Bucuresti, Romania \\ ${ }^{\mathrm{b}}$ Université Catholique de Louvain, Unité Eaux-et-Forêts, Place Croix-du-Sud, 3, Louvain-la-Neuve, Belgium
}

(Received 28 November 2005; accepted 16 June 2006)

\begin{abstract}
As much for the geneticist as for the planter, information on sites, clones, and other factors would be decisive to reduce insect damage on poplars. In this perspective, a study was done in eight field trials in Belgium and in Luxembourg, considering two types of leaf damage on 24 clones from Italy, Belgium and the Netherlands. Damage varied considerably, depending on the clones, sites, species and parental individuals. Clone's ranks concord on the different sites; site's ranks are similar for the various clones. Clones with same parents have similar levels of resistance. The two types of damage are not correlated. Hybrids of $P$. deltoides $\times$ nigra show widespread variability; those with genetic material of $P$. trichocarpa are generally more resistant to caterpillar-like damage. The maximal differences are about 1 to 5 for the clones, and 1 to 10 for the sites. But the most vulnerable clone on the most favourable site was damaged almost 70 times more often than the opposite combination.
\end{abstract}

insect / poplar / clone / parenthood / site

Résumé - Dégâts d'insectes populicoles phyllophages sur différents clones et dans divers sites. Tant pour le généticien que pour le planteur, des informations sur les clones, sites et autres facteurs seraient décisives pour réduire les dommages d'insectes sur peupliers. Dans ce but, une étude, dans huit essais en Belgique et au Luxembourg, a porté sur deux types de phyllophages et 24 clones provenant d'Italie, de Belgique et des Pays-Bas. Les dégâts diffèrent beaucoup en fonction des clones, lieux, espèces et individus parentaux. Le rang des clones concorde d'un site à l'autre; il en est de même des rangs des sites en fonction des clones. Les clones ayant de mêmes parents ont des résistances similaires. Les deux types de dégâts ne semblent pas corrélés. Les hybrides de $P$. deltoides $\times$ nigra montrent une grande variabilité ; ceux avec du matériel génétique de $P$. trichocarpa sont plus résistants aux dégâts de type chenilles. Les différences maximales sont d'environ 1 à 5 pour les clones, de 1 à 10 pour les lieux. Mais le clone le plus sensible dans le site le plus favorable aux insectes est environ 70 fois plus endommagé que la combinaison inverse.

insecte / peuplier / clone / parenté / site

\section{INTRODUCTION}

Poplar trees, ideally adapted to plain landscape, have a higher production than most other species. But insect damage on leaves or on wood can reduce, sometimes drastically, this productivity. Occurrences of such defoliations are very numerous; our bibliography gives only a very limited example (see also: [10,11,23] or www. poplar + defoliators). Damage on leaves we analysed induces a photosynthesis decrease and a production of defence mechanisms inhibiting growth: Nef and Duhoux [22] quote many cases of growth decrease after insect attacks. For instance, attack of Phyllocnistis unipunctella reduces by $25 \%$ the leaf area [5], without any compensation of the photosynthesis [21], but can increase drastically the polyphenols content [20].

The ecological and economic damage caused by insects to poplar trees varies according to several factors. Apart from those linked to the dynamics of the pest population and their enemies, the genetic and sitelinked factors play a crucial role and, in addition, can be profitably controlled by the poplar grower. As such differences can be decisive, research is needed to ascertain what is relevant to site or to genetics aspects.

\footnotetext{
*Corresponding author: nef.1@efor.ucl.ac.be
}

Despite the promising practical possibilities offered by the use of the natural resistance of Salicaceae to pest, too few publications deal with the subject (see for instance the comprehensive reports published by $[2,22]$, or other publications like $[14,15])$.

To obtain reliable and extrapolative results, Nef and Duhoux [22] recommend starting with field research, in different places, then adding complementary result about the site to these initial findings. To contribute to such information, one of us collected, in rigorously similar conditions, samples of hybrid poplars planted on various sites that enabled to correlate the respective damage with the mineral content of the leaves and with the sites characteristics. These two aspects, site and leaf, will be dealt with in later publications, while the present paper will focus essentially on the importance and variability of the damage in terms of genetic factors and of trial fields.

Our first concern was to ascertain the extent of damage, this one being inversely correlated with the intensity of the defence systems. Polyphenols seem to be most frequently used by poplars in such mechanisms, and could be linked to differences in strategy between forest and pioneer poplars [20]. This damage was observed on the different clones and in the different sites and, later on, related to genetic factors. Secondary 
Table I. Trial fields and leaf surfaces (in $\mathrm{cm}^{2}$ ).

\begin{tabular}{|c|c|c|c|c|c|c|}
\hline No. & Site (abbr.) & Date of plantation & $\begin{array}{l}\text { Altitude } \\
\text { (m) }\end{array}$ & $\begin{array}{l}\text { Annual rainfall } \\
(\mathrm{mm})\end{array}$ & $\begin{array}{c}\text { Average temperature } \\
\left({ }^{\circ} \mathrm{C}\right)\end{array}$ & $\begin{array}{l}\text { Average leaf surface } \\
\qquad\left(\mathrm{cm}^{2}\right)\end{array}$ \\
\hline \multicolumn{7}{|c|}{ Planted in 1994} \\
\hline 2 & Lintgen (Lin) & $04 / 02 / 94$ & 226 & 873 & 8.7 & 29.39 \\
\hline 5 & Eugies (Eug) & 20/03/94 & 46 & 788 & 9.3 & 21.54 \\
\hline 6 & Deinze (Dei) & $18 / 03 / 94$ & 8 & 716 & 9,5 & 22.58 \\
\hline 7 & Chastre (Cha) & $15 / 02 / 94$ & 142 & 772 & 8.8 & 19.68 \\
\hline 10 & Baileux (Bai) & $01 / 03 / 94$ & 240 & 1044 & 8.1 & 11.74 \\
\hline \multicolumn{7}{|c|}{ Planted in 1995} \\
\hline 1 & La Reid (LaR) & $15 / 03 / 95$ & 355 & 875 & 8.9 & 9.23 \\
\hline 3 & Gembloux (Gem) & $15 / 02 / 95$ & 165 & 772 & 8.8 & 10.45 \\
\hline 8 & Sugny (Sug) & $15 / 03 / 95$ & 410 & 1146 & 8.0 & 10.61 \\
\hline
\end{tabular}

questions are to rank the clones in function of the damage suffered. Concerning this last point, the clones examined in this experiment are never commercialised all together in any of the countries of origin, and such a ranking would thus be completely useless. Partial ranking could easily be extrapolated from different hereafter results such as those below in Table III.

\section{OBJECTIVES}

In the framework of the present article, the following points are developed:

- What is the quantitative importance of the damage caused by the defoliators?

- Is the leaf area variable and does it influence the damage?

- Do the clones affect leaf susceptibility to insect attacks?

- Do the clones show the same susceptibility to the two types of damage observed?

- In the different sites, do the clones show similar susceptibility to defoliators?

- Do the parent species affect the vulnerability of the clones?

- Do the clones with the same parental individuals reveal a comparable susceptibility?

\section{MATERIAL AND METHODS}

\subsection{Trial fields and clones}

The study used 8 sites established in 1994 and 1995 in the framework of the European project IRPI (International Research on Poplar Improvement, coordinated by S. Bisoffi, Italy). Seven of the fields were located in Belgium, and the eighth (Lintgen) in the Grand Duchy of Luxembourg. Their main characteristics appear in Table I.

Three clones came from the Netherlands, 13 from Italy and 9 from Belgium (cf. also Tab. II). The cuttings came from those countries as well. The Ticino clone was excluded because it showed a high mortality rate, probably caused by bad adaptation to the local climate.

The trees, planted $80 \mathrm{~cm}$ deep, were spaced out $8 \mathrm{~m}$ apart. They were about 4 to $6 \mathrm{~m}$ tall, according to the clone and to the year of
Table II. Clones, origin, genetic group, common parents, leaf surfaces $\left(\right.$ in $\mathrm{cm}^{2}$ ).

\begin{tabular}{|c|c|c|c|c|c|}
\hline No. & Clone & $\begin{array}{l}\text { Country } \\
\text { of origin }\end{array}$ & $\begin{array}{l}\text { Genetic } \\
\text { group }\end{array}$ & $\begin{array}{c}\text { Common } \\
\text { parents }\end{array}$ & $\begin{array}{c}\text { Leaf } \\
\text { surfaces }\end{array}$ \\
\hline 1 & Isonzo & Italy & $\mathrm{D} \times \mathrm{DN}$ & $\mathrm{M} 2+\mathrm{P} 1$ & 15.11 \\
\hline 2 & $71009 / 2$ & Belgium & DT & M4 & 21.13 \\
\hline 3 & Timavo & Italy & $\mathrm{D} \times \mathrm{DN}$ & $\mathrm{M} 2+\mathrm{P} 1$ & 14.68 \\
\hline 4 & Beaupré & Belgium & $\mathrm{TD}$ & M5 & 23.63 \\
\hline 5 & $71015 / 1$ & Belgium & DT & M4 & 21.85 \\
\hline 6 & Enza & Italy & $\mathrm{DN}$ & & 13.63 \\
\hline 7 & Hoogvorst & Belgium & TD & $\mathrm{M} 5+\mathrm{P} 3$ & 20.66 \\
\hline 8 & Dvina & Italy & $\mathrm{D} ?$ & & 22.00 \\
\hline 9 & Koster & Netherlands & $\mathrm{DN}$ & & 13.78 \\
\hline 10 & S681/84 & Belgium & DN & M3 & 11.70 \\
\hline 11 & Brenta & Italy & DN & & 17.95 \\
\hline 12 & Mella & Italy & $\mathrm{DN}$ & & 18.52 \\
\hline 14 & S683/24 & Belgium & $\mathrm{DN}$ & M3 & 12.46 \\
\hline 15 & Ellert & Netherlands & DN & $\mathrm{P} 2$ & 9.68 \\
\hline 16 & Lambro & Italy & DN & & 18.89 \\
\hline 17 & Grimingen & Belgium & $\mathrm{DD} \times \mathrm{TD}$ & & 18.72 \\
\hline 18 & I-214 & Italy & $\mathrm{DN}$ & & 17.08 \\
\hline 19 & Taro & Italy & $\mathrm{DN} \times \mathrm{TD}$ & M1 & 16.78 \\
\hline 20 & Lena & Italy & $\mathrm{D}$ ? & & 20.07 \\
\hline 21 & $71009 / 1$ & Belgium & DT & M4 & 22.19 \\
\hline 22 & Hees & Netherlands & DN & $\mathrm{P} 2$ & 10.74 \\
\hline 23 & Soligo & Italy & DN & M1 & 17.96 \\
\hline 24 & Trebbia & Italy & DN & & 15.04 \\
\hline 25 & Hazendans & Belgium & TD & P3 & 22.82 \\
\hline
\end{tabular}

Key to the "Genetic Groups": In the order: mother, then father. Some examples: $\mathrm{DN}=$ Populus deltoides $\times$ P. nigra $; \mathrm{TD}=$ P. trichocarpa $\times P$. deltoides; $\mathrm{D}$ ? $=P$. deltoides $\times$ father unknown (=Wind pollinated). Key to the common parents: clones with the same mother: $\mathrm{Mx}$; clones with the same father: Px; clones with the same mother and father: $\mathrm{Mx}+\mathrm{Px}$. 
plantation. No special site preparation, such as fertilisation, was applied.

Each trial field consisted of 6 repetitions of 25 clones in an "onetreeperplot" arrangement. In order to restrict the labour, only two repetitions were used, which means that 2 trees per clone and per site were sampled. On each tree, we collected 25 developed leaves of a randomly chosen twig, by avoiding the terminal shoots as well as the lower branches, an optimum to estimate their mineral content [8]. A minimum of about 25 leaves is needed to represent validly a poplar tree. A total number of about 9100 leaves (some samples were not complete) were collected in 1995, of which the individual surface, the damaged area, and the mineral composition were analysed. For each site and clone, 50 leaves were studied, giving good approximations of those variables, which will be proved later on by the very significant results obtained on the basis of this experimental design.

The samples were harvested in June, at the end of the period of the pest activity when damage is maximal. Consequently, most insect pests had disappeared when sampling began, but the few remaining ones permitted some coherent determinations of the concerned defoliators' fauna.

The clones studied were hybrids belonging to the following genetic groups: D?, (clones with unknown father), $\mathrm{D} \times \mathrm{DN}, \mathrm{DN}$, $(\mathrm{DD}) \times(\mathrm{TD}),(\mathrm{DN}) \times(\mathrm{TD})$, and lastly TD or DT (abbreviations explained in Tab. II). The tables of results (Tabs. III and IV) range mainly from the clones with the maximum genetic constituents in $P$. deltoides to those with the maximum genetic weight in $P$. trichocarpa. In our study, no difference was observed between the TD and the DT, and consequently, these will no longer be taken into account.

For a number of interpretations, the first three groups were gathered under the designation " $\Sigma \mathrm{DN}$ " given the parallelism between the results; the same applies to the whole of the other clones designated as Genetic Group " $\Sigma T D$ " with $P$. trichocarpa as a genetic constituent. These interpretations are designated globally by the heading " $\Sigma$ Genetic Groups" (Figs. 4, 5 and 6).

Table II list the clone, the common parents and the average leaf surfaces.

\subsection{Quantification of the damage caused by leaf insect pests}

The surface of each leaf studied was measured separately with the help of an image analyser (NIH Image) and the estimated damaged area was divided into two categories:

- widespread damage often spreading in from the leaf edges, and attributable to caterpillars or sawfly larvae (Fig. 1), hereafter called L1,

- window-like puncturing (Fig. 2) attributable to adult coleoptera, hereafter called L2.

There was negligible trace of typical larval chrysomelid damage.

\subsection{Statistical methods}

Our results used only the absolute values of the leaf surfaces eaten. Other quantifications, such as the frequency of attacks, the percentages of surfaces eaten, or some mathematical transformations, did not enhance the conclusions and were not retained.

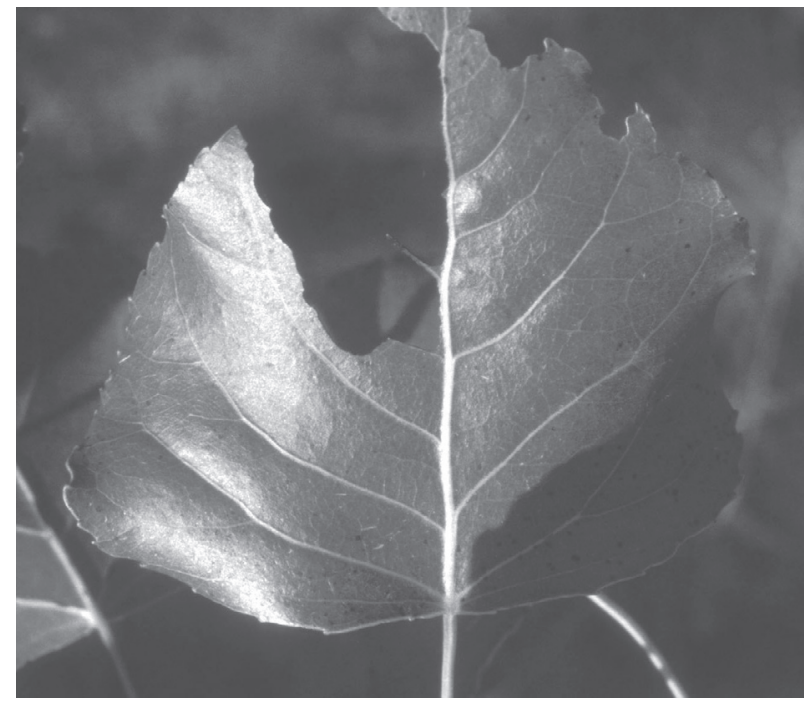

Figure 1. Example of type L1 damage: the leaf is eaten from the edge.

The analyses were preferably performed by starting from average damages on trees, which represents a replication with 25 leaves [9]. In these conditions, the data were distributed between 2 repetitions, 24 clones and 8 sites, or a theoretical total of 384 combinations, actually reduced to 364 , since some data were missing. A variance analysis was applied, with three classification criteria: repetitions, clones and sites. The Proc GLM (Copyright SAS Institute) procedure was used for these analyses.

The Kendall test [24] was used to check the concordance between the results for the clones and for the sites.

\section{RESULTS}

\subsection{Global importance of observed insect damage}

During the study year, type L1 damage covered an average surface of $0.6 \mathrm{~cm}^{2}$ per leaf, while the average surface of type L2 damage was clearly less, only about $0.05 \mathrm{~cm}^{2}$.

The impact of the damage on the trees' physiology is proportional to the surface eaten, and not to its sole absolute value. The global average is $3.5 \%$ for type L1 and $0.3 \%$ for type L2. These preliminary statements will be greatly influenced by the differences due to the clones and to the sites. By way of illustration: for the most vulnerable clone on the most favourable site, $18 \%$ of the foliar surface was destroyed by the L1, but only $0,26 \%$ for the opposite combination.

\subsection{Leaf surfaces}

The leaf surfaces per site and per clone are given in Tables I and II. Statistical analysis revealed a great clonal variability: $\mathrm{F}=27.9^{* * *}$, with 23 and 158 d.f. The site variability is still greater: $\mathrm{F}=275^{* * *}$, with 7 and 8 d.f.

The average leaf surface for the experiments taken as a whole is $17.23 \mathrm{~cm}^{2}$. Their variability, demonstrated by Figure 3 (where lines link the clones with the same parents, cf. 


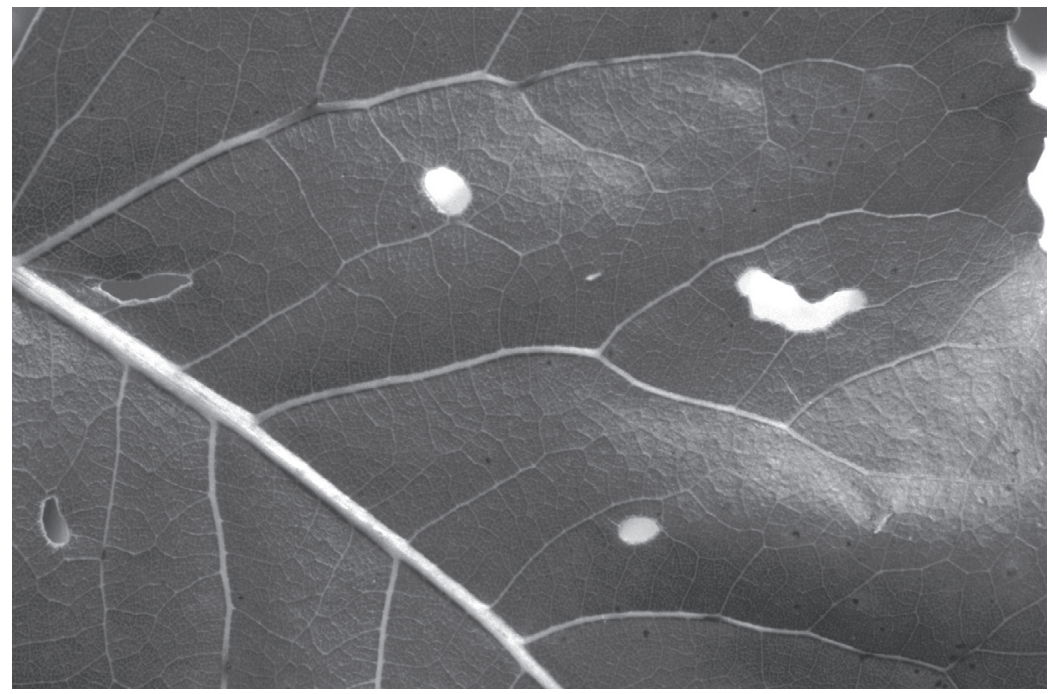

Figure 2. Example of type L2 damage: small window-like puncturing in the leaf blade.

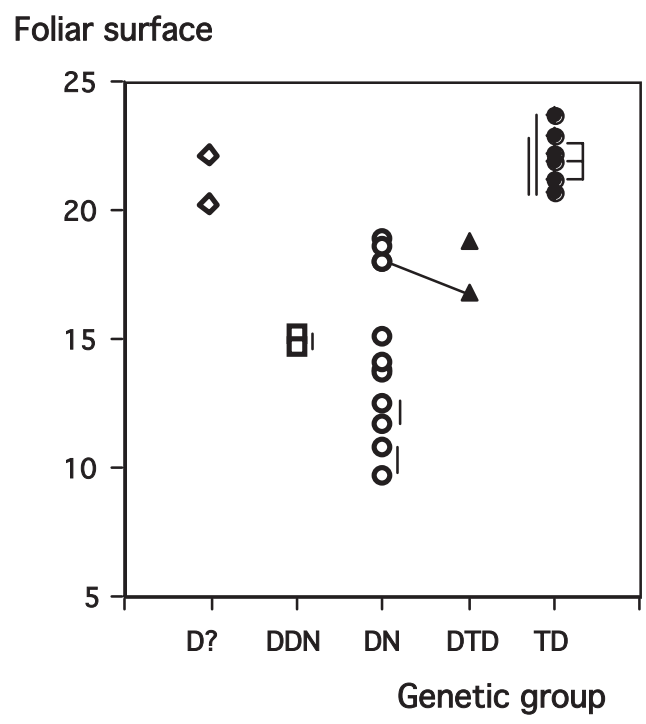

Figure 3. Average leaf surface (in $\mathrm{cm}^{2}$ ) per clone for the genetic groups.

Tab. II) and by the statistical analysis, is first linked to the genetic group: the " $\Sigma \mathrm{DN}$ " poplars usually have smaller leaves (average $13.9 \mathrm{~cm}^{2}$ ) than the " $\Sigma$ TD" poplars (average $21 \mathrm{~cm}^{2}$ ), in agreement with general knowledge about poplars $[12,16]$. The same figure shows the complete break between the DN and the TD clones; the DTD hybrids appear in intermediate position. The hybrids with a nigra genetic constituent have smaller leaves than those of the other groups. The Lena and Dvina clones, father unknown (but $\mathrm{D} \times \mathrm{D}$ as tested by DNA: S. Bisoffi, in litt.) have leaf surfaces similar to those of the trichocarpa hybrids.

From site to site, the leaf surfaces (Tab. I) vary very considerably from 9 to $29 \mathrm{~cm}^{2}$, due to the age of the plantation and, mainly, to site characteristics.

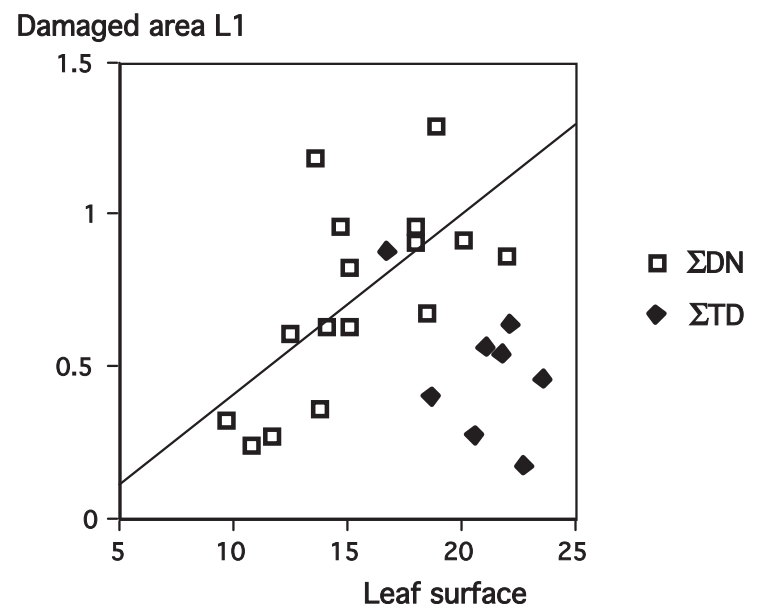

Figure 4. $\mathrm{L} 1$ damaged area $\left(\right.$ in $\mathrm{cm}^{2}$ ) per clone related to the leaf surface (in $\mathrm{cm}^{2}$ ) for the " $\Sigma$ Genetic Groups".

The Kendall test on the full data shows that the clones share similar ranks in the trial fields: $\mathrm{W}=0.60 * * *$, with 23 d.f. and there is a very high rate of concordance between the ranks of the different trial fields: $\mathrm{W}=0.816^{* * *}$, with 7 d.f.: the clones, therefore, react in a parallel way to the site conditions in the various experiments.

\subsection{Influence of the leaf surface on damage intensity}

At first sight, the leaf surfaces do not present any correlation with the surfaces eaten by L1 (Fig. 4). But careful observation reveals a difference: the " $\Sigma \mathrm{DN}$ " group shows a positive correlation with the leaf surface: ( $r=0.654 * *$ for 14 d.f.), while the " $\Sigma$ TD" group does not show such a relationship.

Contrary to the L1, the L2 damage on the clones, either for the " $\Sigma \mathrm{DN}$ " group or for the " $\Sigma$ TD" group, shows no significant relationship with the leaf surfaces (Fig. 5). 
Table III. L1 damage: surfaces eaten (in $\mathrm{cm}^{2}$ ), for the clones and sites.

\begin{tabular}{|c|c|c|c|c|c|c|c|c|c|c|}
\hline \multirow[b]{2}{*}{ Clones } & \multirow[b]{2}{*}{ Genetic } & \multicolumn{7}{|c|}{ Site } & \multirow[b]{2}{*}{ Gem } & \multirow[b]{2}{*}{ Average } \\
\hline & & Lin & Eug & Bai & $\mathrm{LaR}$ & Sug & Cha & Dei & & \\
\hline Lambro & DN & 2.671 & 1.886 & 1.345 & 1.008 & 2.178 & 1.223 & 0.423 & 0.327 & 1.383 \\
\hline Enza & DN & 3.613 & 0.774 & 0.540 & 0.928 & 1.823 & 0.814 & 0.098 & 0.112 & 1.088 \\
\hline Dvina & $\mathrm{D} ?$ & 1.125 & 1.862 & 0.756 & 1.573 & 0.829 & 0.592 & 0.317 & 0.054 & 0.888 \\
\hline Isonzo & $\mathrm{D} \times \mathrm{DN}$ & 0.795 & 1.756 & 1.594 & 0.178 & 1.117 & 0.354 & 0.733 & 0.034 & 0.820 \\
\hline Timavo & $\mathrm{D} \times \mathrm{DN}$ & 1.745 & 1.924 & 1.163 & 0.995 & 1.482 & 0.184 & 0.174 & 0.016 & 0.960 \\
\hline Soligo & DN & 1.038 & 1.824 & 0.451 & 0.557 & 0.358 & 1.699 & 1.476 & 0.263 & 0.958 \\
\hline Lena & $\mathrm{D}$ ? & 0.291 & 1.498 & 0.901 & 2.104 & 0.468 & 1.262 & 0.466 & 0.089 & 0.885 \\
\hline Brenta & DN & 1.396 & 1.798 & 1.684 & 0.804 & 1.080 & 0.103 & 0.058 & 0.301 & 0.903 \\
\hline Taro & $\mathrm{DN} \times \mathrm{TD}$ & 1.168 & 1.423 & 0.901 & 0.379 & 1.953 & 0.349 & 0.469 & 0.052 & 0.837 \\
\hline Mella & DN & 1.317 & 0.708 & 0.550 & 0.834 & 0.282 & 0.950 & 0.632 & 0.089 & 0.670 \\
\hline I-214 & DN & 0.971 & 1.201 & 0.564 & 1.096 & 0.682 & 0.556 & 0.145 & 0.059 & 0.659 \\
\hline $71009 / 1$ & DT & 1.194 & 0.541 & 0.835 & 0.658 & 0.553 & 0.865 & 0.276 & 0.115 & 0.630 \\
\hline Trebbia & DN & 0.875 & 0.841 & 1.395 & 0.903 & 0.515 & 0.202 & 0.167 & 0.263 & 0.645 \\
\hline S683/24 & DN & 0.692 & 0.362 & 2.358 & 0.989 & 0.393 & 0.024 & 0.004 & 0.036 & 0.607 \\
\hline $71009 / 2$ & DT & 1.107 & 0.562 & 0.402 & 1.460 & 0.529 & 0.014 & 0.071 & 0.276 & 0.552 \\
\hline $71015 / 1$ & DT & 1.001 & 1.597 & 0.540 & 0.441 & 0.409 & 0.000 & 0.094 & 0.168 & 0.531 \\
\hline Beaupré & $\mathrm{TD}$ & 0.707 & 0.925 & 0.495 & 1.064 & 0.368 & 0.075 & 0.164 & 0.094 & 0.486 \\
\hline Grimingen & $\mathrm{DD} \times \mathrm{TD}$ & 1.164 & 0.214 & 1.081 & 0.187 & 0.288 & 0.119 & 0.042 & 0.034 & 0.391 \\
\hline Koster & DN & 0.379 & 0.299 & 0.522 & 1.226 & 0.461 & 0.137 & 0.143 & 0.106 & 0.409 \\
\hline Ellert & DN & 0.281 & 0.076 & 0.088 & 0.982 & 0.605 & 0.034 & 0.077 & 0.764 & 0.363 \\
\hline Hoogvorst & TD & 0.421 & 0.165 & 0.756 & 0.348 & 0.340 & 0.041 & 0.018 & 0.039 & 0.266 \\
\hline S681/84 & DN & 0.217 & 0.246 & 0.969 & 0.406 & 0.205 & 0.006 & 0.020 & 0.048 & 0.265 \\
\hline Hees & DN & 0.324 & 0.257 & 0.540 & 0.532 & 0.169 & 0.030 & 0.030 & 0.013 & 0.237 \\
\hline Hazendans & TD & 0.094 & 0.142 & 0.184 & 0.329 & 0.221 & 0.126 & 0.125 & 0.074 & 0.162 \\
\hline Average & & 1.024 & 0.933 & 0.866 & 0.794 & 0.704 & 0.407 & 0.259 & 0.143 & 0.632 \\
\hline
\end{tabular}

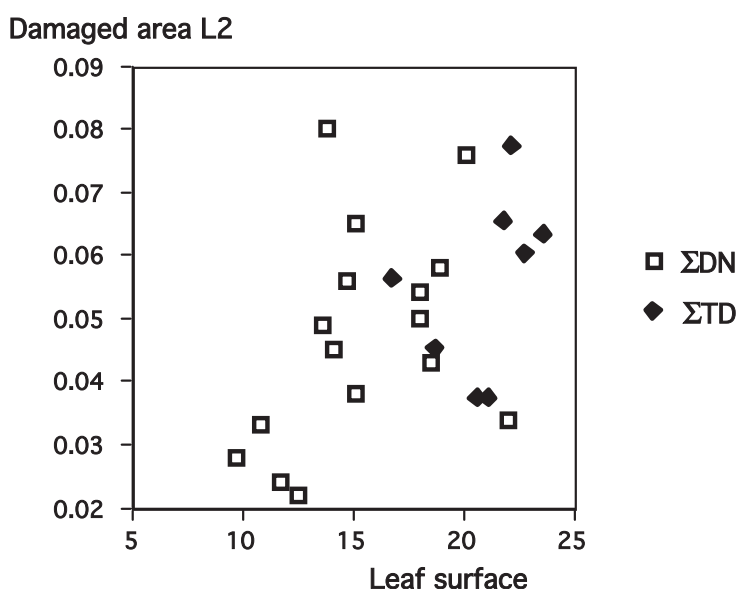

Figure 5. L2 damaged area (in $\mathrm{cm}^{2}$ ) per clone related to the leaf surface $\left(\right.$ in $\mathrm{cm}^{2}$ ) for the " $\Sigma$ Genetic Groups".

\subsection{Variations of insect damage}

For L1 damage, Table III gives the average leaf surface eaten per leaf for every clone and site. Both the clones and the sites are listed from the most susceptible to the most resistant. The genetic groups to which the clones belong are recalled in this Table.

The same method for type L2 is utilised in Table IV.

\subsection{Influence of the clones}

\subsubsection{Type L1 damage}

Clone susceptibility varies strongly, the clone average ranges from $1.38 \mathrm{~cm}^{2}$ for the Lambro to 0.162 for the Hazendans, or a ratio of 1 to 8 (Tab. III). Statistical analysis largely confirms these differences: $\mathrm{F}=8.5^{* * *}$ with 23 and 158 d.f.

The Kendall test shows that the clone ranks reveal an extremely significant concordance on the different sites: $\mathrm{W}=$ $0.385^{* * *}$ with 23 d.f.

\subsubsection{Type L2 damage}

The averages per clone of type 2 damage (Tab. IV) range from $0.08 \mathrm{~cm}^{2}$ (Koster) to 0.02 (S683/24). These differences 
Table IV. L2 damage: surfaces eaten (in $\mathrm{cm}^{2}$ ), for the clones and sites.

\begin{tabular}{|c|c|c|c|c|c|c|c|c|c|c|}
\hline \multirow[b]{2}{*}{ Clones } & \multirow[b]{2}{*}{ Genetic } & \multicolumn{7}{|c|}{ Site } & \multirow[b]{2}{*}{ Lin } & \multirow[b]{2}{*}{ Average } \\
\hline & & Dei & Eug & Gem & Sug & $\mathrm{LaR}$ & Bai & Cha & & \\
\hline Koster & $\mathrm{DN}$ & 0.256 & 0.110 & 0.142 & 0.051 & 0.019 & 0.014 & 0.009 & 0.005 & 0.080 \\
\hline $71009 / 1$ & DT & 0.341 & 0.095 & 0.032 & 0.042 & 0.060 & 0.015 & 0.017 & 0.017 & 0.077 \\
\hline Lena & $\mathrm{D} ?$ & 0.300 & 0.063 & 0.038 & 0.014 & 0.051 & 0.014 & 0.015 & 0.019 & 0.076 \\
\hline $71015 / 1$ & DT & 0.215 & 0.097 & 0.096 & 0.037 & 0.025 & 0.022 & 0.015 & 0.017 & 0.065 \\
\hline Isonzo & $\mathrm{D} \times \mathrm{DN}$ & 0.239 & 0.105 & 0.054 & 0.038 & 0.048 & 0.014 & 0.017 & 0.009 & 0.065 \\
\hline Beaupré & TD & 0.163 & 0.067 & 0.037 & 0.108 & 0.030 & 0.040 & 0.028 & 0.019 & 0.063 \\
\hline Hazendans & $\mathrm{TD}$ & 0.262 & 0.050 & 0.008 & 0.043 & 0.037 & 0.049 & 0.015 & 0.015 & 0.060 \\
\hline Lambro & $\mathrm{DN}$ & 0.240 & 0.032 & 0.023 & 0.040 & 0.026 & 0.008 & 0.022 & 0.025 & 0.058 \\
\hline Timavo & $\mathrm{D} \times \mathrm{DN}$ & 0.215 & 0.039 & 0.076 & 0.049 & 0.023 & 0.022 & 0.013 & 0.010 & 0.056 \\
\hline Taro & $\mathrm{DN} \times \mathrm{TD}$ & 0.180 & 0.098 & 0.067 & 0.016 & 0.021 & 0.014 & 0.024 & 0.007 & 0.056 \\
\hline Brenta & $\mathrm{DN}$ & 0.047 & 0.103 & 0.154 & 0.061 & 0.012 & 0.026 & 0.022 & 0.008 & 0.054 \\
\hline Soligo & DN & 0.219 & 0.078 & 0.036 & 0.013 & 0.012 & 0.009 & 0.009 & 0.025 & 0.050 \\
\hline Enza & $\mathrm{DN}$ & 0.198 & 0.032 & 0.016 & 0.054 & 0.003 & 0.022 & 0.011 & 0.005 & 0.049 \\
\hline I 214 & DN & 0.098 & 0.045 & 0.085 & 0.034 & 0.026 & 0.038 & 0.012 & 0.017 & 0.045 \\
\hline Grimingen & $\mathrm{DD} \times \mathrm{TD}$ & 0.169 & 0.070 & 0.005 & 0.011 & 0.033 & 0.012 & 0.044 & 0.012 & 0.045 \\
\hline Mella & $\mathrm{DN}$ & 0.105 & 0.032 & 0.075 & 0.050 & 0.058 & 0.015 & 0.010 & 0.006 & 0.043 \\
\hline Trebbia & $\mathrm{DN}$ & 0.153 & 0.024 & 0.049 & 0.021 & 0.029 & 0.012 & 0.009 & 0.003 & 0.038 \\
\hline $71009 / 2$ & DT & 0.057 & 0.061 & 0.017 & 0.048 & 0.077 & 0.015 & 0.014 & 0.005 & 0.037 \\
\hline Hoogvorst & $\mathrm{TD}$ & 0.116 & 0.042 & 0.021 & 0.030 & 0.043 & 0.017 & 0.019 & 0.005 & 0.037 \\
\hline Dvina & $\mathrm{D}$ ? & 0.096 & 0.026 & 0.039 & 0.017 & 0.048 & 0.017 & 0.017 & 0.004 & 0.034 \\
\hline Hees & DN & 0.125 & 0.011 & 0.056 & 0.020 & 0.035 & 0.003 & 0.012 & 0.006 & 0.033 \\
\hline Ellert & $\mathrm{DN}$ & 0.109 & 0.029 & 0.014 & 0.044 & 0.014 & 0.002 & 0.004 & 0.004 & 0.028 \\
\hline S681/84 & $\mathrm{DN}$ & 0.058 & 0.048 & 0.044 & 0.006 & 0.008 & 0.008 & 0.015 & 0.008 & 0.024 \\
\hline S683/24 & DN & 0.072 & 0.025 & 0.015 & 0.020 & 0.014 & 0.005 & 0.013 & 0.010 & 0.021 \\
\hline Averages & & 0.168 & 0.058 & 0.050 & 0.036 & 0.032 & 0.017 & 0.016 & 0.011 & 0.050 \\
\hline
\end{tabular}

are very significant: the Anova reveals an important general variability due to the clones: $\mathrm{F}=3.63 * * *$ with 23 and 158 d.f.

The Kendall test applied to the clones from one site to the next one shows clearcut concordance again: $\mathrm{W}=0.252 * * *$ with 23 d.f.

\subsubsection{Correlation between L1 and L2 damage per clone}

Taken as a whole, damage types L1 and L2 reveal no correlation (Fig. 6).

However, the " $\Sigma$ DN" group shows a clear tendency towards correlation, and this becomes very significant when excluding the Koster clone (Fig.6: $r=0.69 * *$ with 13 d.f.) which produced quite aberrant results on some sites

In contrast, the balance insectplant for the " $\Sigma$ TD" group might depend more on specific resistance mechanisms different for the L1 and for the L2.

\subsection{Influence of the genetic groups and common parents}

\subsubsection{Type L1 damage}

The susceptibilities per genetic group differ sharply (Fig. 7). On average, the TD are more resistant than the DN

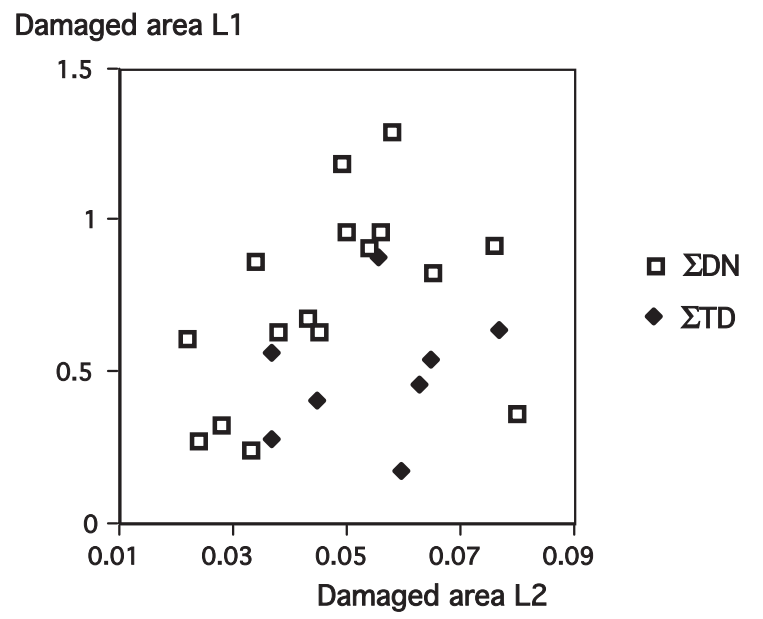

Figure 6. Relationship between the damaged area L1 and L2 par clone for the " $\Sigma$ Genetic Groups" (in $\mathrm{cm}^{2}$ ).

clones but in this case (in contrast to the leaf surfaces, Fig. 3), the values partly overlap. While some DN are certainly more susceptible than the TD, others are equally resistant. Such information would be of benefit to the selector's work. 


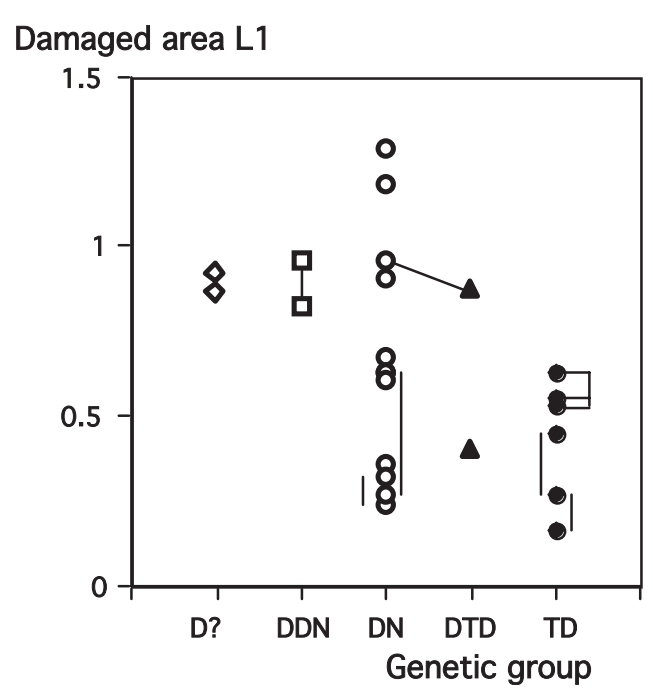

Figure 7. L1 damage: average surfaces eaten per clone (in $\mathrm{cm}^{2}$ ) for the genetic groups.

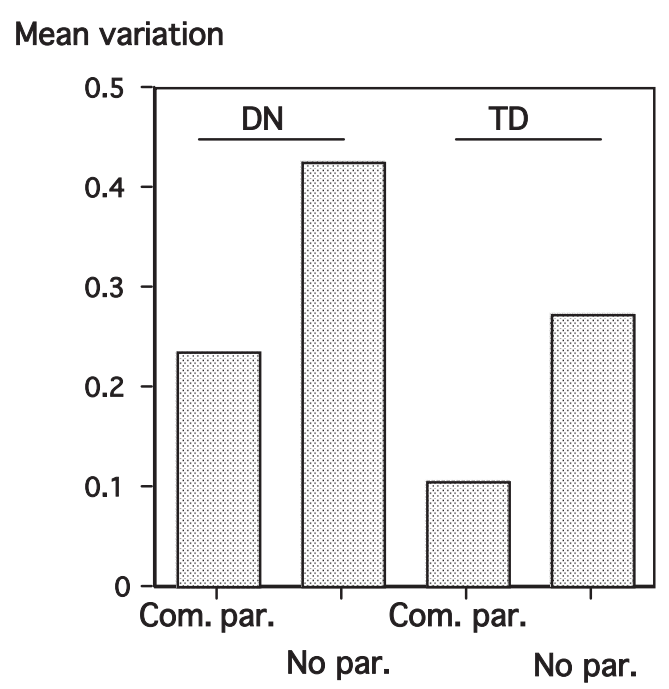

Figure 8. L1 damage for the DN and TD Groups: average variations between clones with common parents (Com. par.) and those without them (No par.).

Another advantageous result for the selector lies in the susceptibilities of clones with the same fathers and/or mothers (Fig. 7, a line joins them) because they do not vary as significantly as in the clones without such parenthood. Figure 8 quantifies a number of these differences.

\subsubsection{Type L2 damage}

Contrary to L1 damage, the genetic groups do not have a clearcut effect on the susceptibilities to leaf eating insects. Table IV and Figure 9 show that the insect damages are widely scattered. The susceptibilities of the " $\Sigma$ TD" with common parents, compared to those without common parents, are much

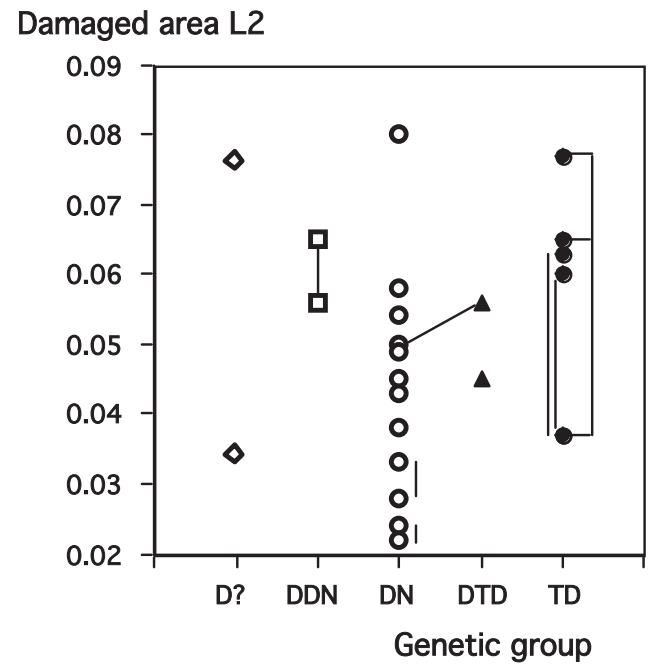

Figure 9. L2 damaged area per clone (in $\mathrm{cm}^{2}$ ), for the genetic groups.

further apart. In contrast, the susceptibilities of the " $\Sigma \mathrm{DN}$ " with common parents are very similar.

\subsection{Influence of the trial fields}

\subsubsection{Type L1 damage}

For the L1 damage (Tab. III), the averages range from $1.024 \mathrm{~cm}^{2}$ at Lintgen, the most vulnerable site, to $0.143 \mathrm{~cm}^{2}$ at Gembloux. These differences are much more significant than for the clones: the site variability is $\mathrm{F}=34.01 * * *$ with 7 and 8 d.f. They tend to form two distinct groups, characterized by their vulnerability: trial fields 2, 5, 10, 1 and 8 were infested much more significantly than fields 7, 6 and 3 .

The Kendall test verified that the clones occupied similar ranks in the different sites: $\mathrm{W}=0.498 * * *$ with 7 d.f.

\subsubsection{Type L2 damage}

For L2 damage (Tab. IV), the dispersal of the results is much broader with $0.168 \mathrm{~cm}^{2}$ at Deinze and $0.011 \mathrm{~cm}^{2}$ at Lintgen. The Anova confirms the high variability between the field trials: $\mathrm{F}=118.7 * * *$ with 7 and 8 d.f. The first site was more heavily infested than the next four; trial fields 10,7 and 2 were the most resistant.

The concordance between clone ranks in relation with the sites is very significant. $\mathrm{W}=0.631 * * *$ with 7 d.f.

\subsubsection{Relation $L 1-L 2$}

No significant correlation was found between L1 and L2 damage per trial field (Fig. 10), and even the site most susceptible to the L2 (Deinze), proved one of the most resistant to the L1. Hence we reiterate the hypothesis that both types of damage are linked to different means of resistance. 


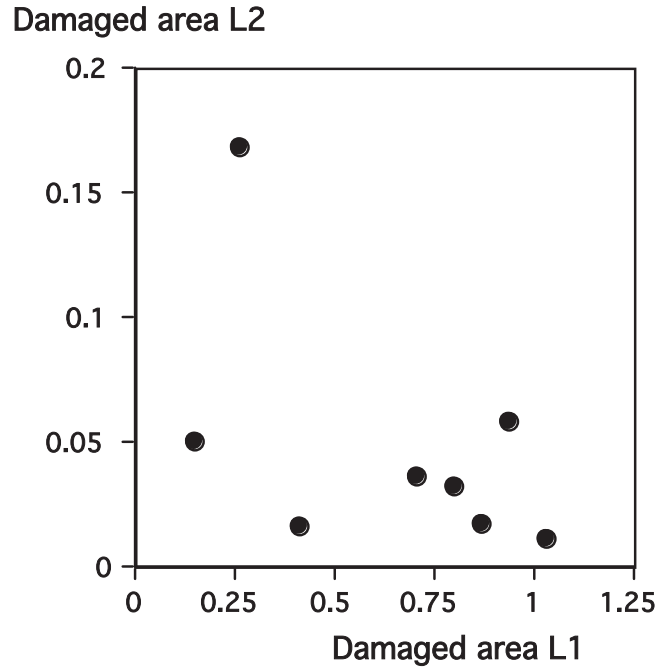

Figure 10. Relationship between the damaged area L1 and L2 per site (in $\mathrm{cm}^{2}$ ).

\subsection{Joint influence of clones and sites}

The concordance between the clones and sites classifications also allows drawing a conclusion of special interest to poplar planters. The extent of the damage to the most infested clone in the most susceptible trial field can be estimated and the same is achieved between the two minimal values (this approach is preferable to treating the real values, because the estimation mitigates the random variations and gives a better overall picture of the phenomenon [9]).

As far as the L1 is concerned, the damage for the Lambro clone in Lintgen is estimated at $2.36 \mathrm{~cm}^{2}$, whereas it is limited to $0.03 \mathrm{~cm}^{2}$ for the Hazendans clone in Gembloux. There is a ratio of 62 to 1 between the two. With regard to L2 damage, the extremes are $0.27 \mathrm{~cm}^{2}$ (Koster in Deinze) and $0.004 \mathrm{~cm}^{2}$ (S 683/2 in Lintgen), or a ratio of 67 to 1.

Therefore, the planting of a resistant clone on a site unfavourable to insects would reduce the attacks to an enormous extent.

\section{DISCUSSION}

\subsection{Damage intensity}

Only moderate damage was noted during the study year. The insects causing type L1 damage (caterpillar-like damage) only destroyed an average of $3.5 \%$ of the leaves (with a maximum of $18 \%$ ), while type L2 damage (coleoptera-like damage) was limited to $0.3 \%$. The observed damages were by far less important than pullulations destroying the entire leafage: Allegro and Augustin [2], Nef and Duhoux [22] quote many examples of such infestations caused by Operothera brumata, Leucoma salicis, Chrysomelidae and many other larvae. Such pullulation generates secondary resistance mechanisms that utilize energy and could reduce tree growth.
Our study covers only a sample of small population, but perhaps this factor helped us to obtain more accurate results: by greater damage (the maximum being a complete defoliation), the results would become more and more similar, and the conclusions would thus decrease in validity. However, preferences between poplars can sometimes vary according to insect density [3] or other factors [7].

\subsection{Influence of leaf surface on damage}

For the " $\Sigma$ TD" group, L1 and L2 damage is independent of the leaf surface; the clonal specific resistance mechanisms might explain the differences.

Where the " $\Sigma \mathrm{DN}$ " clones are concerned, the largest leaves are those most exposed to the L1 damage; the L2 damage does not show more than a similar trend. So, this factor for the DN hybrids could become one of the selector's first criteria to control L1 damaging insects.

Two hypotheses could explain this phenomenon. On the one hand, the larger leaves would supposedly attract more L1 individuals in search of a site for their eggs and also more L2 looking for food. However, in addition to this, the larger leaves would be damaged to a greater extent by the L1. This explanation is unsatisfactory: an insect eats to cover its food needs and not because of the leaf surface available. (Notice that the leaves are not entirely eaten away). Perhaps the smaller leaves are thicker, by way of compensation, so that the insect is satisfied with a smaller surface for the same amount of food. Another more likely hypothesis is that clones with larger leaves might contain more attractive or appetizing elements or include less deterrent. Nef [19] gives the following example: the greater the amount of tannin in the leaf, the longer the galleries of Phyllocnistis unipunctella, and the thinner the chrysalis produced. The content in nitrogenous compounds can also play an important role [13]. This phenomenon will be discussed in a later publication.

The leaf surfaces vary from site to site, but neither the L1 nor the L2 damage is correlated with these differences in location. This goes to prove that the extent of the damage is not caused mechanically by the leaf surface but that chemical explanations are more likely.

\subsection{Variations due to clones and trial fields}

The clones generate variations of the damage in the proportion of 1 to 8 for the L1 and 1 to 4 for the L2. Variability between the DN hybrids is clearly much greater than between the TD hybrids. The trial fields themselves reveal still more significant variations: from 1 to 8 (L1) and even 1 to 15 (L2).

For L1 damage, there is a very significant concordance between the respective ranks of the clones used in the different places, and in the reactions of the clones to the site characteristics. Those results confirm the hypothesis that these classifications are not fortuitous, but due to genetic or stationrelated systematic effects, probably of chemical nature. The results are 
not so clear for the L2, which are about 10 times less abundant, and thus less quantifiable.

Between the most susceptible clone on the site most favourable to the insects, and the most resistant clone on the unfavourable site, the estimated differences, in our experiments, is not far from 70 to 1 . This conclusion is of the utmost importance from a practical point of view because the correct choice of clone and station will be of considerable weight for preventing insect damage. This point has been raised in other publications, quoted by Nef and Duhoux [22], but our present results quantify the very large difference due to those factors and confirm the necessity of such research.

\subsection{Influences of the genetic groups and common parents}

The dispersal of the " $\Sigma \mathrm{DN}$ " clones would suggest that several resistance mechanisms are implied. Other authors, such as Charan-Singh and Singh [6] and Nef [17], have highlighted the great variability of the resistance in this group. This evidence supports the hypothesis of the polygenic type resistance: Allegro [1], Augustin and Delplanque [4] referred to by Allegro and Augustin [2].

The " $\Sigma T D "$ are on average much more resistant to L1 insects damage. For the L2 damage, the results of the " $\Sigma$ TD" clones are aberrant: the most probable explanation to this situation may be a random variation between too low frequencies.

The clones with the same parents have clearly similar resistance. This link between the susceptibility of the clones and the species or parental individuals means that our results can be extrapolated and applied to new crossings. For the geneticist, resistance to insects can be a major element in the selection of new clones, all the more so because this resistance is at work in parallel in different stations. However, the selector must remember that the resistance of poplars to pests is very variable and that, in consequence, resistance to pests specific to the planting site will have to be investigated. Generally speaking, the clones with one $P$. trichocarpa are, on average and often significantly, more resistant to type L1 defoliators. This finding corresponds, among others, to those of Gruppe et al. [14] and James and Newcombe [15]. Contrariwise, these clones tend to be preferred by L 2 defoliators, probably coleoptera, which is close to the results quoted by Allegro and Augustin [2]. Another example: the pure $P$. trichocarpa clones are very susceptible to the leaf miner Zeugophora flavicollis, a coleoptera which is inhibited by the deltoides genes in the DN and TD hybrids, whereas the lepidoptera miner Stigmella trimaculella prefers the DN but is inhibited by the trichocarpa genes [17, 18].

No result indicates that paternal genetic influence on pest resistance differs from that of the mother's.

Acknowledgements: Great help and numerous contacts were required to complete our study. The Catholic University of Louvain awarded a grant to Dr. R. Tomescu to develop and implement the research. P. Mertens (Station for Forest Research Gembloux and
GRAPP, Task 5, Belgium) and J.C. Kiefer (Task 5, Luxembourg) provided all the information on the IRPI project. C. Larcin, gave us the benefit of his knowledge of poplars and provided us with transport. The analysis of statistics was discussed with, or done, by P. Berthet, P. Dagnelie, S. Dupont, E. Lecoutre. Weather data were obtained from the Belgian Institut Royal de Météorologie. The anonymous reviewers of the Annals provided very useful comments to improve the definitive text.

The authors kindly address their most sincere thanks to all these persons and Institutions.

\section{REFERENCES}

[1] Allegro G., Susceptibility of different poplar species to the Fall Webworm (Hyphantria cunea Drury), International Poplar Commission, W.P. on insects and other animal pests, Izmit (Turkey), 1994, 6 p.

[2] Allegro G., Augustin S., Recent advances in poplar resistance to insect pests in Europe (1992-1999), International Poplar Commission, W.P. on insects and other animal pests, Portland (USA), 2000, $6 \mathrm{p}$.

[3] Augustin S., Courtin C., Delplanque A., Preferences of Chrysomela populi $\mathrm{L}$. and $C$. tremulae $\mathrm{F}$. for Leuce section poplar clones, J. Appl. Ent. 115 (1993) 370-378.

[4] Augustin S., Delplanque A., Final technical report of the EC funded project AIRIRPI, Subtask 2.3: Biochemical markers, (1995), 79-110.

[5] Bouhaiche M., Nef L., Relations entre les attaques de Phyllocnistis suffusella, la croissance et la composition minérale des feuilles de peupliers, Meded. Fac. Landbouww. Rijksuniv. Gent, 52, 3/A (1987) 259-266.

[6] Charan-Singh P., Singh C., Natural resistance in poplar against Eucosma glaciata, Meyrick, Indian J. For. 21/4 (1998) 316-320.

[7] Chaudry I., Ahmad I., Population dynamics of two poplar defoliators (final report), Pakistan Forest Institute, Peshawar, 1973, 62 p.

[8] Chen S., Ceulemans R., Impens I., A fractal-based Populus canopy structure model for the calculation of light interception, For. Ecol. Manage. 69 (1992) 97-110.

[9] Dagnelie P., Statistique théorique et appliquée, T.2 : Inférence statistique à une et à deux dimensions, De Boeck \& Larcier, Paris \& Bruxelles, 1998.

[10] Delplanque A., Les insectes associés aux peupliers, Memor, Bruxelles, 1998

[11] De Tillesse V., Nef L., Les insectes dommageables au peuplier - Espèces d'importance internationale, International Poplar Commission/FAO, 1998, URL: www.efor.ucl.ac.be/ipc/pub/ nef01/nef01f.htm (or see: insectes dommageables au peuplier).

[12] FAO, Peupliers et saules dans la production du bois et l'utilisation des terres, Roma, 1980

[13] Gielen B., Ceulemans R., The likely impact of rising atmospheric $\mathrm{CO}_{2}$ on natural and managed Populus: a literature review, Environ. Pollut. 115 (2001) 335-358.

[14] Gruppe A., Fusseder M., Schopf R., Makeschin P., Short rotation plantations of aspen and balsam poplar on former arable land in Germany: defoliating insects and leaf constituents, For. Ecol. Manage. 121 (1999) 113-122. 
[15] James R.R., Newcombe G., Defoliation patterns and genetics of insects resistance in cottonwood, Can. J. For. Res. 30 (2000) 85-90.

[16] Mertens P. (Ed.), Le Peuplier en Wallonie et dans les régions voisines, Ministère Région Wallonne, Jambes/Namur, 2003.

[17] Nef L., Relation entre certaines caractéristiques des peupliers et l'abondance d'insectes phytophages, Z. Ang. Ent. 99 (1985) $160-170$.

[18] Nef L., De populierinsekten in België in 1979-1983: voorkomen, onderzoek, Bull. Soc. R. For. Belg. 92 (1985) 153-162.

[19] Nef L., Interactions between the leaf miner Phyllocnistis suffusella and poplar, in Mattson W., Levieux J., Bernard-Dagan C. (Eds.), Mechanisms of woody plant defenses against insects, SpringerVerlag, Berlin, 1988, pp. 239-251.
[20] Nef L., Stratégies écologiques et de défense de peupliers forestiers et de peupliers pionniers (submitted).

[21] Nef L., Ceulemans R., Menu J.F., Influence of Phyllocnistis suffusella attacks on gas exchange of poplar leaves, Proceedings International Poplar Commission, Zaragoza, 1992, 335-338.

[22] Nef L., Duhoux F., Poplar and willow resistance to insects. Proceedings International Poplar Commission, Zaragoza, 1992, $307-325$.

[23] Nef L., Janssens F., Les insectes nuisibles au Peuplier en Belgique et en Europe Occidentale, C.L.I.I.F., U.C.L., Louvain-la-Neuve, 1982.

[24] Siegel S., Nonparametric Statistics, McGrawHill, N.Y., London, 1956 (Quoting: Kendall M.G., Rank correlation methods, Griffin, London, 1948). 